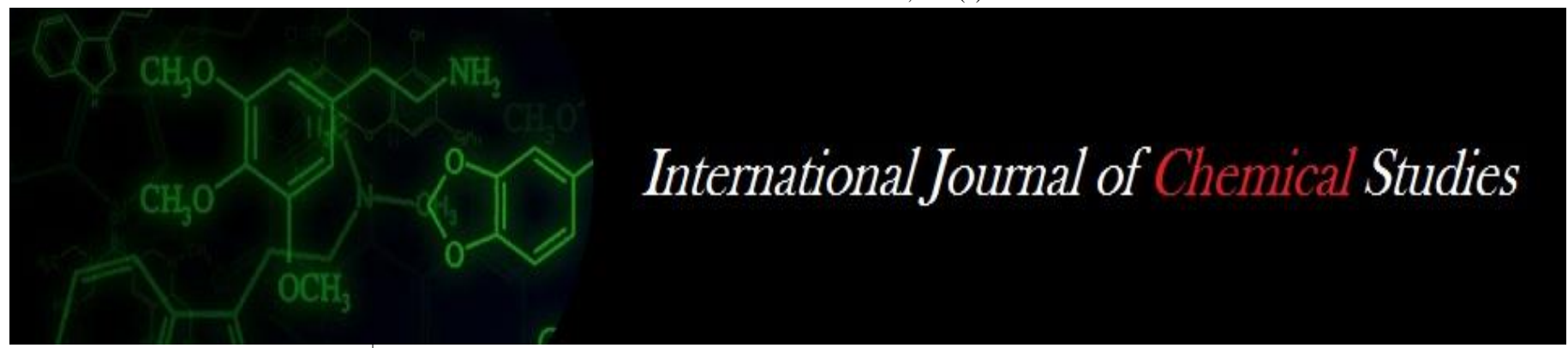

P-ISSN: 2349-8528

E-ISSN: 2321-4902

www.chemijournal.com

IJCS 2021; SP-9(1): 166-170

(C) 2021 IJCS

Received: 04-11-2020

Accepted: 10-12-2020

Sonali S Lad

M.Sc. Student, Department of Agril. Entomology, College of Agriculture, Dapoli, Dr.

Balasaheb Sawant Konkan

Krishi Vidyapeeth, Dapoli,

Ratnagiri, Maharashtra, India

KV Naik

Professor (CAS), Department of

Agril. Entomology, College of

Agriculture, Dapoli, Dr.

Balasaheb Sawant Konkan

Krishi Vidyapeeth, Dapoli,

Ratnagiri, Maharashtra, India

\section{MS Karmarkar}

Assistant Professor, Department of Agril. Entomology, College of Agriculture, Dapoli, Dr.

Balasaheb Sawant Konkan

Krishi Vidyapeeth, Dapoli,

Ratnagiri, Maharashtra, India

\section{GM Golvankar}

Ph.D., Scholar, Department of Agril. Entomology, College of Agriculture, Dapoli, Dr.

Balasaheb Sawant Konkan

Krishi Vidyapeeth, Dapoli,

Ratnagiri, Maharashtra, India

Corresponding Author:

Sonali S Lad

M.Sc. Student, Department of Agril. Entomology, College of Agriculture, Dapoli, Dr. Balasaheb Sawant Konkan Krishi Vidyapeeth, Dapoli, Ratnagiri, Maharashtra, India

\section{Bio-efficacy of insecticides against thrips infesting bitter gourd}

\author{
Sonali S Lad, KV Naik, MS Karmarkar and GM Golvankar
}

DOI: https://doi.org/10.22271/chemi.2021.v9.i1d.11559

\begin{abstract}
The present investigation was carried out to study the bio-efficacy of insecticides against thrips infesting bitter gourd during rabi-summer season of 2017-18 at Centre of Excellence for Mango, College of Agriculture, Dapoli, Dist. Ratnagiri (M.S).

There were six insecticides tested against thrips infesting bitter gourd. The results regarding overall mean of three sprays against thrips infesting bitter gourd revealed that the treatment chlorantraniliprole $18.5 \mathrm{SC}$ @ 0.005 per cent was the best treatment which recorded minimum (2.41) population of thrips and was at par with malathion 50 EC @ 0.05 per cent (2.84) and spinosad 45 SC @ 0.014 per cent (3.05). The next effective treatment was emamectin benzoate 5 SG @ 0.002 (3.53) which was at par with treatments azadirachtin 1 EC @ 0.003 per cent (3.65) and lambda cyhalothrin 5 EC @ 0.0025 per cent (3.75). All the treatments were significantly superior over untreated control. The maximum (6.78) thrips population was observed in the untreated control.
\end{abstract}

Keywords: Bio-efficacy, insecticides, thrips, bitter gourd

\section{Introduction}

Bitter gourd is considered as a very important vegetable crop. Therefore, this crop was chosen as an experimental crop in this investigation. It is well known that the piercing sucking insects cause yield losses in vegetable crops as well as other crops (El-Khouly et al., 1998) ${ }^{[3]}$. Among these insect pests, certain Homoptera such as aphids and white flies, Thysanoptera such as thrips have great economic importance which cause serious damage either directly by sucking plant juice or indirectly as vectors of plant pathogenic viruses. (El-Lakwah, 2011 [2]

Thrips tabaci Lindeman (Thysanoptera: Thripidae) both the nymphs and adults lacerate the tissue and suck the sap from upper and lower surfaces of leaves, flowers and stem. In heavy thrips infestation, the leaves became slivery due to the formation of white patches or streaks which finally caused scarring and distortion of leaves and cup upward (Janu et al., 2017) ${ }^{[4]}$. They are susceptible to environmental changes and because of the polyphagous nature of species, one can determine their abundance by the types of plant formations. They are also essential elements of the soil, occurring at depths of 10-30 cm in the soil (Ananthakrishnan, 1984) ${ }^{[1]}$.

There are several management tactics used by farmers for management of thrips in cucurbits crops. But most of the farmers are prefer the chemical management practices due to immediate effect to reduce pest pressure on crops. So, keeping all of these things in mind and present investigation was carried out to study the bio-efficacy of insecticides against thrips infesting bitter gourd during rabi-summer season.

\section{Materials and Methods}

A field experiment was conducted during rabi - summer season of 2017-18 to study the effectiveness of some insecticides against thrips infesting bitter gourd. The details of experiment are given below:

\section{Cultural operations}

The land was prepared as per the requirements of bitter gourd crop and cleared by removing the residues of the previous crop. The experiment was laid in Randomized Block Design (RBD). 
The recommended dose of fertilizers for bitter gourd is 120:60:30 NPK kg/ha. Nitrogen@120 kg/ha was applied in three split doses viz., first dose of 40 per cent $\mathrm{N}$ at the time of sowing, second dose of 40 per cent $\mathrm{N}$ after 30 days of sowing and remaining 20 per cent dose of $\mathrm{N}$ after 60 days of sowing. Phosphorus was applied @ $60 \mathrm{~kg} / \mathrm{ha}$ and potassium was applied @ $30 \mathrm{~kg} / \mathrm{ha}$, these fertilizers were applied in single dose at the time of sowing.

The experimental area was sown with good quality seed of bitter gourd (cv. Kokan Tara). The other agronomic operations and weeding were done as per recommendation.

\section{Experimental details}

\begin{tabular}{|c|c|c|}
\hline Location & : & $\begin{array}{l}\text { Centre of excellence for mango, College } \\
\text { of Agriculture, Dapoli }\end{array}$ \\
\hline Period of study & $:$ & February 2018 to May 2018 \\
\hline Statistical design & : & Randomized Block Design (RBD) \\
\hline No. of replication & : & Three \\
\hline No. of treatments & : & Seven \\
\hline Size of treatment plot & : & $7.5 \mathrm{~m}^{2}$ \\
\hline Total plot size & : & $282 \mathrm{~m}^{2}$ \\
\hline Date of sowing & $:$ & $22^{\text {nd }}$ February 2018 \\
\hline Method of planting & $:$ & On small hills \\
\hline Spacing & : & $1.50 \mathrm{~m} \mathrm{X} 0.50 \mathrm{~m}$ \\
\hline Cultivar & : & Kokan Tara \\
\hline
\end{tabular}

\section{Treatment details}

Treatment No.
$\mathrm{T}_{1}$
$\mathrm{~T}_{2}$
$\mathrm{~T}_{3}$
$\mathrm{~T}_{4}$
$\mathrm{~T}_{5}$
$\mathrm{~T}_{6}$
$\mathrm{~T}_{7}$

$\begin{array}{cc}\text { Treatments } & \text { Conc. }(\%) \\ \text { Azadirachtin 1 EC } & 0.003 \\ \text { Spinosad 45 SC } & 0.014 \\ \text { Emamectin benzoate 5 SG } & 0.002 \\ \text { Chlorantraniliprole 18.5 SC } & 0.005 \\ \text { Lambda cyhalothrin 5 EC } & 0.0025 \\ \text { Malathion 50 EC } & 0.05 \\ \text { Untreated Control } & -\end{array}$

\section{Spraying}

The quantity of spray suspension required for each treatment was calibrated by spraying water over three plots in the experiment prior to the application of insecticide. Spray suspension of desired strength of each insecticide was prepared against pests infesting bitter gourd.

The insecticides were sprayed thrice. First spray of each insecticide was applied when incidence was noticed, while the other two sprays were given at an interval of 15 days with manually operated knapsack sprayer.

\section{Method of recording observations}

To study the efficacy of different insecticides against thrips infesting bitter gourd, the pre-treatment observations were recorded one day before each spray and subsequently post treatment observations were recorded at $3^{\text {rd }}, 7^{\text {th }}, 10^{\text {th }}$ and $14^{\text {th }}$ days after spraying. The pre-count observations were recorded one day before application of insecticides. The observations at $14^{\text {th }}$ days after first and second spray were considered as precount observation of second and third spray. The numbers of thrips from top, middle and bottom leaf were recorded for damage of these pests.

The data thus obtained were converted to appropriate transformation and then analyzed statistically.

\section{Results and Discussion}

1. Efficacy of some insecticides against thrips infesting bitter gourd recorded at different intervals after first spray: The data pertaining to the efficacy of different insecticides against thrips infesting bitter gourd at $3^{\text {rd }}, 7^{\text {th }}, 10^{\text {th }}$ and $14^{\text {th }}$ days after first spray are presented in Table 1.
The data on mean population of thrips prior to insecticide application ranged from 10.07 to 10.54 . There was no significant difference among the different treatments since uniform distribution of thrips was observed in different treatments.

The observations recorded on third day after spraying of insecticide ranged from 5.57 to 12.55 . The treatment chlorantraniliprole 18.5 SC @ 0.005 per cent was found to be most effective treatment which recorded 5.57 mean population of thrips and was at par with the treatment malathion 50 EC @ 0.05 per cent (6.03), spinosad 45 SC @ 0.014 per cent (7.19) and lambda cyhalothrin 5 EC @ 0.0025 per cent (8.13). The next effective treatments were emamectin benzoate 5 SG @0.002 (8.48) and azadirachtin1 EC @ 0.003 per cent (8.53) and both were at par with each other. The maximum (12.55) thrips population was found in untreated control.

At the seventh day after first spray the minimum (4.28) thrips population recorded in the treatment chlorantraniliprole 18.5 SC @ 0.005 per cent which was at par with treatment malathion 50 EC @ 0.05 per cent (4.86). The next effective treatment was spinosad 45 SC @ 0.014 per cent (5.64) which was at par with emamectin benzoate 5 SG @ 0.002 (6.18). The remaining effective treatments were azadirachtin 1 EC @ 0.003 per cent (6.71) and lambda cyhalothrin 5 EC @ 0.0025 per cent (7.18). The maximum (13.37) thrips population was noticed in untreated control.

The observations recorded at $10^{\text {th }}$ day after first spray revealed that the treatment chlorantraniliprole 18.5 SC @ 0.005 per cent $(2.75)$ was found to be most effective which was at par with treatment malathion 50 EC @ 0.05 per cent (3.02) and spinosad 45 SC @ 0.014 per cent (3.07). The next effective treatment was emamectin benzoate 5 SG @ 0.002 (3.90) which was at par with the treatments azadirachtin $1 \mathrm{EC}$ @ 0.003 per cent (3.93) and lambda cyhalothrin 5 EC @ 0.0025 per cent $(4.07)$. The maximum (8.53) thrips population was recorded in untreated plot.

At $14^{\text {th }}$ day of observation, the minimum (3.08) thrips population was recorded in chlorantraniliprole 18.5 SC @ 0.005 per cent and which was at par with malathion 50 EC @ 0.05 per cent (3.87) and spinosad 45 SC @ 0.014 per cent (3.90). The treatment emamectin benzoate 5 SG @ 0.002 (4.13) was at par with the treatments viz., azadirachtin 1 EC @ 0.003 per cent (4.18) and lambda cyhalothrin 5 EC @ 0.0025 per cent $(4.24)$. The maximum population (7.67) was found in untreated plot.

The result regarding overall mean population of thrips infesting bitter gourd after first spray revealed that the treatment chlorantraniliprole 18.5 SC @ 0.005 per cent was the best treatment which recorded minimum (3.92) population of thrips and was at par with malathion 50 EC @ 0.05 per cent (4.45) and spinosad 45 SC @ 0.014 per cent (4.97). The next effective treatment was emamectin benzoate 5 SG @ 0.002 (5.67) was at par with treatments viz., azadirachtin 1 EC @ 0.003 per cent (5.84) and lambda cyhalothrin 5 EC @ 0.0025 per cent $(5.91)$. All the treatments were significantly superior over untreated control. The maximum thrips population (10.53) observed in the untreated control.

2. Efficacy of some insecticides against thrips recorded at different intervals after second spray: The results regarding efficacy of some insecticides against thrips recorded at different intervals after second spray are presented in Table 2. The observations recorded at third day after second spray indicated that the treatment chlorantraniliprole 18.5 SC @ 
0.005 per cent was found to be most effective treatment which recorded 2.88 mean thrips population per three leaves per plant and was at par with malathion 50 EC @ 0.05 per cent (3.48) and spinosad 45 SC @ 0.014 per cent (3.55). The next effective treatment emamectin benzoate 5 SG @ 0.002 (3.88) was at par with treatments azadirachtin 1 EC @ 0.003 per cent (4.02) and lambda cyhalothrin 5 EC @ 0.0025 per cent (4.07). The maximum (7.35) mean thrips population per three leaves per plant was noticed in untreated control.

At $7^{\text {th }}$ day after second spray, the minimum population was recorded in the treatment chlorantraniliprole 18.5 SC @ 0.005 per cent (2.45) was found to be most effective which was at par with treatment malathion 50 EC @ 0.05 per cent (3.08) and spinosad 45 SC @ 0.014 per cent (3.18). The next effective treatment was emamectin benzoate 5 SG @ 0.002 (3.74) which was at par with the treatments viz., azadirachtin 1 EC @ 0.003 per cent (3.87) and lambda cyhalothrin 5 EC @ 0.0025 per cent (3.90). While, maximum (7.08) thrips population was observed in untreated control.

The observations recorded at $10^{\text {th }}$ day after second spray revealed that the treatment chlorantraniliprole 18.5 SC @ 0.005 per cent $(1.90)$ was at par with treatments malathion 50 EC@ 0.05 per cent (2.30) and spinosad 45 SC @ 0.014 per cent (3.37). The remaining treatments in descending order of effectiveness were emamectin benzoate 5 SG @ 0.002 (2.77), azadirachtin 1 EC @ 0.003 per cent (2.98) and lambda cyhalothrin 5 EC @ 0.0025 per cent (3.17). The maximum pest population 5.93 recorded in untreated control.

At $14^{\text {th }}$ day of observation, the minimum (2.08) population of thrips was recorded in chlorantraniliprole 18.5 SC @ 0.005 per cent which was at par with treatments viz., malathion 50 EC @ 0.05 per cent (2.43) and spinosad 45 SC @ 0.014 per cent $(2.47)$. The remaining treatments in descending order of effectiveness were emamectin benzoate 5 SG @ 0.002 (3.27), azadirachtin 1 EC @ 0.003 per cent (3.38) and lambda cyhalothrin 5 EC @ 0.0025 per cent (3.58). The maximum (5.33) population was observed in untreated control.

The result regarding overall mean population of thrips infesting bitter gourd after second spray revealed that the treatment chlorantraniliprole 18.5 SC @ 0.005 per cent was the best treatment which recorded minimum (2.32) population of thrips and was at par with malathion 50 EC @ 0.05 per cent (2.82) and spinosad 45 SC @ 0.014 per cent (2.89). The next effective treatment was emamectin benzoate 5 SG @ 0.002 (3.41) was at par with treatments azadirachtin 1 EC @ 0.003 per cent (3.56) and lambda cyhalothrin 5 EC @ 0.0025 per cent (3.68). All the treatments were significantly superior over untreated control. The maximum (6.42) thrips population was observed in the untreated control.

\section{Efficacy of some insecticides against thrips recorded at different intervals after third spray}

The results regarding efficacy of some insecticides against thrips recorded at different intervals after third spray are presented in Table 3.

After 3 days of third spray, the treatment chlorantraniliprole 18.5 SC@ 0.005 per cent was found most effective which recorded 1.77 mean thrips population per three leaves per plant and it was at par with malathion 50 EC @ 0.05 per cent (2.18) and spinosad 45 SC @ 0.014 per cent (2.28). The treatments emamectin benzoate 5 SG @ 0.002 (2.87) and azadirachtin 1 EC @ 0.003 per cent (2.92) was at par with each other, followed by lambda cyhalothrin 5 EC @ 0.0025 per cent (3.17). The maximum thrips population was noticed in untreated control (4.40).
The data at $7^{\text {th }}$ day of third spray indicated that chlorantraniliprole 18.5 SC @ 0.005 per cent (1.57) was found to be most effective treatment which was at par with treatment malathion 50 EC @ 0.05 per cent (1.94) and spinosad 45 SC @ 0.014 per cent (2.00). The next effective treatment emamectin benzoate 5 SG @ 0.002 (2.07) which was at par with azadirachtin 1 EC @ 0.003 per cent (2.17) and lambda cyhalothrin 5 EC @ 0.0025 per cent (2.27). The untreated control was recorded 3.35 thrips population.

The observations recorded at $10^{\text {th }}$ day after third spray revealed that chlorantraniliprole 18.5 SC @ 0.005 per cent showed better results amongst the treatments with 0.62 mean thrips population and was at par with malathion 50 EC @ 0.05 per cent $(0.87)$ and spinosad 45 SC @ 0.014 per cent (0.88). The treatment emamectin benzoate 5 SG @ 0.002 (1.07) was at par with treatments azadirachtin 1 EC @ 0.003 per cent (1.08) and lambda cyhalothrin 5 EC @ 0.0025 per cent (1.13). Untreated plot recorded maximum (3.12) mean thrips population per three leaves per plant.

At $14^{\text {th }}$ day of observation, no thrips population was recorded in chlorantraniliprole 18.5 SC @ 0.005 per cent which was at par with remaining all treatments viz., malathion 50 EC @ 0.05 per cent (0.02), spinosad 45 SC @ 0.014 per cent (0.03), emamectin benzoate 5 SG @ $0.002(0.04)$, azadirachtin 1 EC @ 0.003 per cent $(0.08)$ and lambda cyhalothrin 5 EC @ 0.0025 per cent $(0.10)$. While untreated control recorded maximum (2.90) pest population.

The result regarding overall mean population of thrips infesting bitter gourd after third spray revealed that the treatment chlorantraniliprole 18.5 SC @ 0.005 per cent was the best treatment which recorded minimum (0.99) population of thrips and was at par with spinosad 45 SC @ 0.014 per cent (1.29) and malathion 50 EC @ 0.05 per cent (1.25). The next effective treatment was emamectin benzoate 5 SG @ 0.002 (1.51) which was at par with treatments azadirachtin 1 EC @ 0.003 per cent (1.56) and lambda cyhalothrin 5 EC @ 0.0025 per cent (1.82). All the treatments were significantly superior over untreated control. The maximum (3.44) thrips population was observed in the untreated control.

\section{Cumulative efficacy of different insecticides against thrips infesting bitter gourd}

The data pertaining to the cumulative efficacy of different insecticides against thrips infesting bitter gourd are presented in Table 4.

The results regarding overall mean of three sprays against thrips infesting bitter gourd revealed that the treatment chlorantraniliprole 18.5 SC @ 0.005 per cent was the best treatment which recorded minimum (2.41) population of thrips and was at par with malathion 50 EC @ 0.05 per cent (2.84) and spinosad 45 SC @ 0.014 per cent (3.05). The next effective treatment was emamectin benzoate 5 SG @ 0.002 (3.53) which was at par with treatments azadirachtin 1 EC @ 0.003 per cent (3.65) and lambda cyhalothrin 5 EC @ 0.0025 per cent (3.75). All the treatments were significantly superior over untreated control. The maximum (6.78) thrips population was observed in the untreated control.

The present results are more or less supported by Dakshina Seal (2011) ${ }^{[5]}$. She revealed that spinosad, spinetoram, chlorofenapyr and formatenate hydrochloride provided a significant level (>90\%) of control. Among new insecticides, rynaxypyr and cyazypyr were effective in providing 50 per cent to 65 per cent reduction of thrips (T. palmi) in melons. 
Table 1: Efficacy of different insecticides against thrips infesting bitter gourd after first spray

\begin{tabular}{|c|c|c|c|c|c|c|c|}
\hline \multirow{2}{*}{ Treatment } & \multirow{2}{*}{ Conc. $(\%)$} & \multicolumn{5}{|c|}{ Mean population of thrips per three leaves per plant } & \multirow{2}{*}{ Overall Mean } \\
\hline & & Pre-count & 3 DAS & 7 DAS & 10 DAS & 14 DAS & \\
\hline Azadirachtin $1 \mathrm{EC}$ & 0.003 & $10.20(3.34)^{*}$ & $8.53(3.09)$ & $6.71(2.77)$ & $3.932 .22)$ & $4.18(2.28)$ & $5.84(2.62)$ \\
\hline Spinosad 45 SC & 0.014 & $10.07(3.31)$ & $7.19(2.84)$ & $5.64(2.57)$ & $3.07(2.01)$ & $3.90(2.21)$ & $4.97(2.44)$ \\
\hline Emamectin benzoate $5 \mathrm{SG}$ & 0.002 & $10.40(3.37)$ & $8.48(3.08)$ & $6.18(2.68)$ & $3.90(2.21)$ & $4.13(2.26)$ & $5.67(2.58)$ \\
\hline Chlorantraniliprole $18.5 \mathrm{SC}$ & 0.005 & $10.40(3.37)$ & $5.57(2.56)$ & $4.28(2.29)$ & $2.75(1.93)$ & $3.08(2.02)$ & $3.92(2.22)$ \\
\hline Lambda cyhalothrin 5 EC & 0.0025 & $10.47(3.38)$ & $8.13(3.01)$ & $7.18(2.86)$ & $4.07(2.25)$ & $4.24(2.29)$ & $5.91(2.63)$ \\
\hline Malathion $50 \mathrm{EC}$ & 0.05 & $10.03(3.32)$ & $6.03(2.65)$ & $4.86(2.41)$ & $3.02(2.00)$ & $3.87(2.21)$ & $4.45(2.33)$ \\
\hline Untreated Control & - & $10.54(3.39)$ & $12.55(3.67)$ & $13.37(3.79)$ & $8.53(3.08)$ & $7.67(2.94)$ & $10.53(3.40)$ \\
\hline S.Em. \pm & & 0.14 & 0.16 & 0.11 & 0.08 & 0.07 & 0.11 \\
\hline $\mathrm{CD}(\mathrm{p}=0.05)$ & & NS & 0.49 & 0.35 & 0.25 & 0.20 & 0.32 \\
\hline
\end{tabular}

*Figures in parentheses are $\sqrt{\mathrm{X}+1}$ values

DAS: Days After Sowing

Table 2: Efficacy of different insecticides against thrips infesting bitter gourd after second spray

\begin{tabular}{|c|c|c|c|c|c|c|c|}
\hline \multirow{2}{*}{ Treatment } & \multirow{2}{*}{ Conc. (\%) } & \multicolumn{5}{|c|}{ Mean population of thrips per three leaves per plant } & \multirow{2}{*}{ Overall Mean } \\
\hline & & Pre-count & 3 DAS & 7 DAS & 10 DAS & 14 DAS & \\
\hline Azadirachtin 1 EC & 0.003 & $4.18(2.28)^{*}$ & $4.02(2.24)$ & $3.87(2.20)$ & $2.98(1.99)$ & $3.38(2.09)$ & $3.56(2.14)$ \\
\hline Spinosad $45 \mathrm{SC}$ & 0.014 & $3.96(2.21)$ & $3.55(2.13)$ & $3.18(2.04)$ & $2.37(1.83)$ & $2.47(1.86)$ & $2.89(1.97)$ \\
\hline Emamectin benzoate $5 \mathrm{SG}$ & 0.002 & $4.13(2.26)$ & $3.88(2.20)$ & $3.74(2.17)$ & $2.77(1.94)$ & $3.27(2.06)$ & $3.41(2.10)$ \\
\hline Chlorantraniliprole $18.5 \mathrm{SC}$ & 0.005 & $3.08(2.02)$ & $2.88(1.97)$ & $2.45(1.85)$ & $1.90(1.70)$ & $2.08(1.76)$ & $2.32(1.82)$ \\
\hline Lambda cyhalothrin 5 EC & 0.0025 & $4.24(2.24)$ & $4.07(2.25)$ & $3.90(2.21)$ & $3.17(2.04)$ & $3.58(2.14)$ & $3.68(2.16)$ \\
\hline Malathion $50 \mathrm{EC}$ & 0.05 & $3.87(2.21)$ & $3.48(2.11)$ & $3.08(2.02)$ & $2.30(1.81)$ & $2.43(1.85)$ & $2.82(1.95)$ \\
\hline Untreated Control & - & $7.67(2.94)$ & $7.35(2.89)$ & $7.08(2.84)$ & $5.93(2.63)$ & $5.33(2.51)$ & $6.42(2.72)$ \\
\hline S.Em.土 & & 0.07 & 0.07 & 0.07 & 0.07 & 0.06 & 0.06 \\
\hline $\mathrm{CD}(\mathrm{p}=0.05)$ & & 0.20 & 0.22 & 0.20 & 0.22 & 0.17 & 0.20 \\
\hline
\end{tabular}

*Figures in parentheses are $\sqrt{\mathrm{X}+1}$ values

DAS: Days After Sowing

Table 3: Efficacy of different insecticides against thrips infesting bitter gourd after third spray

\begin{tabular}{|c|c|c|c|c|c|c|c|}
\hline \multirow{2}{*}{ Treatment } & \multirow{2}{*}{ Conc. $(\%)$} & \multicolumn{5}{|c|}{ Mean population of thrips per three leaves per plant } & \multirow{2}{*}{ Overall Mean } \\
\hline & & Pre-count & 3 DAS & 7 DAS & 10 DAS & 14 DAS & \\
\hline Azadirachtin $1 \mathrm{EC}$ & 0.003 & $3.38(2.09)^{*}$ & $2.92(1.98)$ & $2.17(1.78)$ & $1.08(1.44)$ & $0.08(1.04)$ & $1.56(1.60)$ \\
\hline Spinosad 45 SC & 0.014 & $2.47(1.86)$ & $2.28(1.81)$ & $2.00(1.73)$ & $0.88(1.37)$ & $0.03(1.02)$ & $1.29(1.51)$ \\
\hline Emamectin benzoate $5 \mathrm{SG}$ & 0.002 & $3.27(2.06)$ & $2.87(1.97)$ & $2.07(1.75)$ & $1.07(1.44)$ & $0.04(1.03)$ & $1.51(1.58)$ \\
\hline Chlorantraniliprole $18.5 \mathrm{SC}$ & 0.005 & $2.08(1.76)$ & $1.77(1.66)$ & $1.57(1.60)$ & $0.62(1.27)$ & $0.00(1.00)$ & $0.99(1.41)$ \\
\hline Lambda cyhalothrin 5 EC & 0.0025 & $3.58(2.14)$ & $3.17(2.04)$ & $2.27(1.81)$ & $1.13(1.46)$ & $0.10(1.05)$ & $1.82(1.68)$ \\
\hline Malathion $50 \mathrm{EC}$ & 0.05 & $2.43(1.85)$ & $2.18(1.77)$ & $1.94(1.72)$ & $0.87(1.36)$ & $0.02(1.01)$ & $1.25(1.50)$ \\
\hline Untreated Control & - & $5.33(2.51)$ & $4.40(2.32)$ & $3.35(2.13)$ & $3.12(2.03)$ & $2.90(1.97)$ & $3.44(2.11)$ \\
\hline S.Em. \pm & & 0.06 & 0.10 & 0.04 & 0.05 & 0.02 & 0.05 \\
\hline $\mathrm{CD}(\mathrm{p}=0.05)$ & & 0.17 & 0.30 & 0.13 & 0.15 & 0.06 & 0.16 \\
\hline
\end{tabular}

*Figures in parentheses are $\sqrt{\mathrm{X}+1}$ values

DAS: Days After Sowing

Table 4: Cumulative efficacy of different insecticides against aphids infesting bitter gourd

\begin{tabular}{|c|c|c|c|c|c|}
\hline \multirow{2}{*}{ Treatment } & \multirow{2}{*}{ Conc. $(\%)$} & \multicolumn{3}{|c|}{ Mean population of aphids per three leaves per plant } & \multirow{2}{*}{ Cumulative mean population } \\
\hline & & First spray & Second spray & Third spray & \\
\hline Azadirachtin $1 \mathrm{EC}$ & 0.003 & $5.84(2.62)^{*}$ & $3.56(2.14)$ & $1.56(1.60)$ & $3.65(2.16)$ \\
\hline Spinosad 45 SC & 0.014 & $4.97(2.44)$ & $2.89(1.97)$ & $1.29(1.51)$ & $3.05(2.01)$ \\
\hline Emamectin benzoate $5 \mathrm{SG}$ & 0.002 & $5.67(2.58)$ & $3.41(2.10)$ & $1.51(1.58)$ & $3.53(2.13)$ \\
\hline Chlorantraniliprole 18.5 SC & 0.005 & $3.92(2.22)$ & $2.32(1.82)$ & $0.99(1.41)$ & $2.41(1.85)$ \\
\hline Lambda cyhalothrin 5 EC & 0.0025 & $5.91(2.63)$ & $3.68(2.16)$ & $1.82(1.68)$ & $3.75(2.18)$ \\
\hline Malathion $50 \mathrm{EC}$ & 0.05 & $4.45(2.33)$ & 2.82() 1.95 & $1.25(1.50)$ & $2.84(1.96)$ \\
\hline Untreated Control & - & $10.53(3.40)$ & $6.42(2.72)$ & $3.44(2.11)$ & $6.78(2.79)$ \\
\hline S.Em. \pm & & 0.11 & 0.06 & 0.05 & 0.07 \\
\hline $\mathrm{CD}(\mathrm{p}=0.05)$ & & 0.32 & 0.20 & 0.16 & 0.23 \\
\hline
\end{tabular}

*Figures in parentheses are $\sqrt{\mathrm{X}+1}$ values

DAS: Days After Sowing

\section{Conclusion}

Among the tested insecticides three spray of chlorantraniliprole 18.5 SC @ 0.005 per cent was found to be the best treatment followed by malathion 50 EC @ 0.05 per cent and spinosad 45 SC @ 0.014 per cent against thrips.

\section{References}

1. Ananthakrishnan TN. Bioecology of thrips. Oak Park, MI: Indira Publ. House 1984, 233.

2. El-Lakwah FA, Abd-wahab HA, Kattab MM, Azaba, ElGhanam MS. Population dynamics of some pests 
infesting nili cucumber plantations in relation to certain ecological factors. J Agric. Res 2011;89(1):137-153.

3. El-Khouly AS, Khalafalla EME, Metwally MM, Helal HA, El-Mezaien AB. Seasonal abundance and population dynamics of certain sucking insects on soybed in kafr ElSheikh Gvernorate. Egypt. J. Agric. Res 1998;76(1):141151.

4. Janu A, Dahiya KK, Jakhar P. Population dynamics of thrips, Thrips tabaci Lindemann in American cotton (Gossypium hirsutum). Inter. J. Curr. Micro. and Appl. Sci 2017;6(7):203-209.

5. Seal Dakshina R. Abundance and management of melon thrips, Thrips palmi Karny (Thysanoptera: Thripidae). Proc. Fla. State Hort. Soc 2011;124:140-143. 